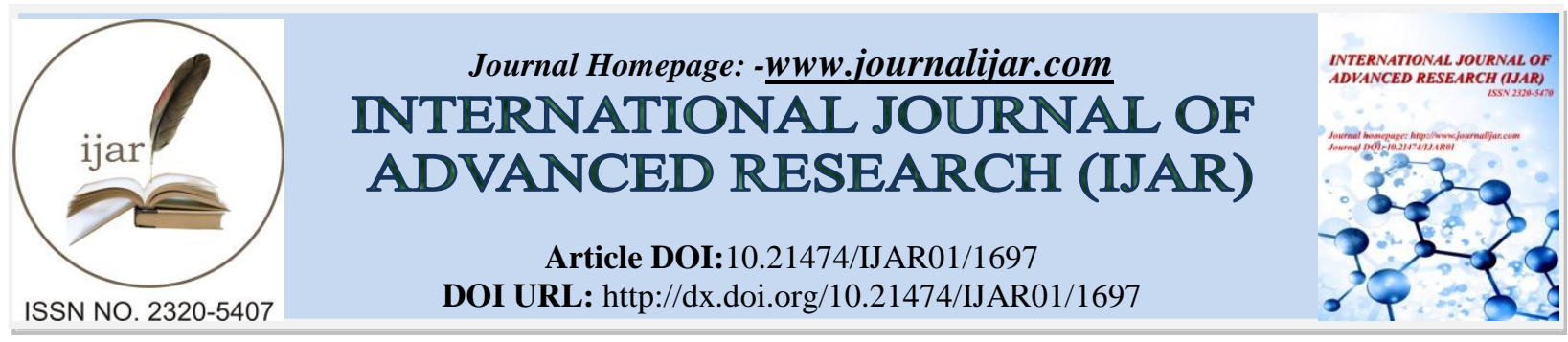

RESEARCH ARTICLE

\title{
EFFECT ON BIOCHEMICAL PARAMETERS OF CYANOBACTERIUM ANABAENA SP UNDER LEAD STRESS.
}

Pratibha Rani Deep, Shantanu Bhattacharyya and Binata Nayak.

School of Life Sciences, Sambalpur University, JyotiVihar, Sambalpur, Odisha, India-768019

\section{Manuscript Info}

Manuscript History

Received: 12 July 2016

Final Accepted: 22 August 2016

Published: September 2016

Key words:-

Anabaena, MDA, SOD, Heterocyst

frequency, lead toxicity

\section{Abstract}

Effect of lead on Anabaena sp at five different concentrations (0.1, $0.5,1,1.5$ and $2 \mathrm{ppm}$ ) were examined. Parameters such as growth response, pigment content, total protein content, and membrane damage, photosynthetic efficiency of PS II, SOD activity and heterocyst frequency were evaluated in laboratory conditions under control and treated conditions. Growth rate in all treated samples were much slower as compared to the control and the rate further decreased as the concentration of lead and days of incubation increased. The heavy metal toxicity is best observed by changes in growth of the algae. Protein content, photosynthetic pigment content (chl- $a$ and car) and photosynthetic efficiency in terms of $\mathrm{Fv} / \mathrm{Fm}$ of PSII. MDA accumulation in the alga in the treated sample is much higher as compared to control and the accumulation gradually increased as the day of exposure and concentration of heavy metal increased. SOD activity increased with increase in lead concentration and was observed maximum in $2 \mathrm{ppm}$ as compared to control. Heterocyst frequency also decreased with increase in lead concentration and found to be minimum in treated sample.

Copy Right, IJAR, 2016,. All rights reserved.

\section{Introduction:-}

Heavy metal causes serious environmental pollution. Contamination of the aquatic environment by heavy metals has been a subject of much concern in the recent years. It has become a worldwide phenomenon and their levels vary depending upon natural and anthropogenic pollution (Isanietal., 2009). With the rapid development of many industries (mining, surface finishing, energy and fuel producing, fertilizer, pesticides, metallurgy, iron and steel, electroplating, electrolysis, electro-osmosis, leather, photography, electric appliances manufacturing, metal surface treating) and aerospace and atomic energy wastes containing metals are directly or indirectly discharged into the environment causing serious environmental pollution and threatening human life (Gavrilescu, 2004; Malkoc and Nuhoglu, 2005; and Kumar et al., 2009). Several physico-chemical treatments like ion exchange (Volesky, 1994), chemical precipitation, electrochemical treatment (Atkinson et al., 1998), membrane technologies, adsorption or activated carbon etc are being used for the removal of heavy metals ions from aqueous wastes (Volesky, 2001). But these treatments are costly and end-product is usually high concentrated metal-loaded sludge, which is difficult to be disposed of (Atkinson et al., 1998). In contrast phycoremediation emerged as a good option (Gupta et al., 2000, Pavasantet al., 2006; Vijayaraghavanet al., 2006) and use of algal biomass as a biosorbent has emerged as an attractive, economical and effective bioremediating agent due to certain added advantages over others 
(Matheickaland Yu, 1999; Matheickalet al., 1998). Application of microbial biomass to remove toxic heavy metals has become relatively popular owing to its high adsorbing capacity and low cost (Bay Ramoglu and arica, 2008; Doshi et al., 2007b). Many blue green algae have remarkable affinity for heavy metals (Raiet al., 2000) and grow frequently in metal contaminated sites. They are also used as a bioremediator of heavy metal in aquatic bodies (Nakanishi et al., 2004). Cyanobacteria can grow in heavy metal polluted environments display ability to tolerate high concentrations of those metals and are effective biological metal sorbents (Thajuddin and Subramanian, 2005) so cyanobacteria can be used as a sink to remove heavy metals from the environment and are often used for phytoremediation. These are considered as potential biosorbents because they are easy to handle, can be mass cultivated easily, possess relatively high surface area and have high metal binding affinity (Tienet al., 2005; Khattaret al., 2007). Heavy metals uptake by cyanobacteria has received less attention, compared to algae but now its demand is increasing day by day (Viner, 1987; Matagi et al., 1998). The BGA and GA are able to bind large amount of metals due to presence of mucilaginous sheath (Wang et al., 1998; Tien, 2002) via absorption/adsorption processes (El-Enany and Issa, 2000). The toxicity of heavy metals to algae and cyanobacteria has been observed since 1939 (Whitton, 1970). Toxicity tolerance of heavy metals by algae and cyanobacteria are noticed as many of them are still found living in the contaminated soils and water bodies (Whitton, 1970). Several studies have also been reported about the possible uses of algae and cyanobacteria for monitoring heavy metal pollution (Whitton and Say, 1981; Feriset al., 2003). Cyanobacteria, as a group, are thought to have survived a wide spectrum of global environmental stresses such as high and low temperature, drought, salinity, nitrogen starvation, photo oxidation, anaerobiosis, osmotic and chemical stresses (Fay, 1992; Tandeau de Marsac and Houmard, 1993; Das and Adhikary, 1996; Shikha and Singh, 2004; Xia, 2005). The cosmopolitan distribution and their presence as symbiotic organism show a high variability in adaptation to diverse environmental factors. Cyanobacteria when exposed to elevated concentrations of heavy metals results in growth inhibition (Marschene, 1995), reduced light harvesting pigments (Tripathiet al., 1981; Xylander and Braune, 1994) and changes in photosynthetic electron transport system (Singh etal., 1991). Heavy metals like $\mathrm{Cd}, \mathrm{Ni}, \mathrm{Hg}$ and $\mathrm{Cr}$ showed inhibition of growth, pigment synthesis, nutrient uptake, nitrogen fixation and photosynthesis in Anabaena inequalis, Anabaena doliolum and Nostocmuscorum (Stratton et al., 1979; Rai and Raizada, 1985).

Lead is one of the major heavy metal used in pipes, drains, and soldering materials and mostly it is used in batteries. Apart from the natural weathering processes, the other lead contamination factor of the environment are mining, smelting activities, paints (Malik, 2004), gasoline, explosives and disposal of municipal sewage sludges (Ryan and Chaney, 1994). Exposure to lead produces anemia, liver and kidney damage, brain damage and ultimately death (Henick-Kling and Stoewasnd, 1993). Lead is a toxic metal with no biological function (Allen, 1984). Lead is found to be more toxic metal than nickel, copper and zinc as reported in Anabaenasp (Hemlata and Fatma, 2009). Studies have also shown that lead inhibits metabolic processes such as nitrogen assimilation, photosynthesis, respiration, water uptake and transcription (Krupaet al., 1993). Lead ions $\left(\mathrm{Pb}^{+2}\right)$ can intensify processes of ROS production leading to oxidative stress (Cuyperset al., 1999; Foyer et al., 1997). These processes destructively effect cell structure and metabolism which are mutually connected with each other, by decreasing the efficiency of oxidationreduction enzymes or the electron transport systems in the cell (Stroinski and Kozlowska, 1997). Many genera of cyanobacteria are reported to be used to remove heavy metals e.g. Tolypothrixtenuis, Calothixparietinashow high ability to remove mercury, Scytonemaschnidlei, Anabaena cylindrical, A. torulosa have high cadmium removal efficiency at 96-98\%. Gloeocapsa sp., Nostocpaludosum, N. piscinale, N. punctiformae, N. commune, Oscillatoriaagardhii, PhormidiummolleandTolypothrix remove 90-96\% of lead. Aphanothecehalophytica and Spirulinaplatensiscould remove only $22 \%$ and $35 \%$ of lead respectively from battery factory wastewater (Kitjaharn and Incharoensakdi, 1992) and (Incharoensakdi and Kitjaharn, 1998). As blue green algae has much more potential for heavy metal removal from contaminated sites, in this study Anabaena spisolated from local industrial water bodies was chosen to study the effect of lead on some biochemical parameters.

\section{Material and Methods:-} Maintenance of culture:-

Test algae Anabaena sp were obtained from Cyanolab, School of Life Sciences, Sambalpur University. These samples were grown in nitrogen free BG-11 medium (Stanieret al., 1971). Flask capacity of $250 \mathrm{ml}$ was used as algal culture medium under laboratory condition. Axenic culture in log-phage were inoculated in experiment and maintained under controlled conditions of light $\left(7.5 \mathrm{~W} / \mathrm{m}^{2}\right)$ and temperature $\left(26 \pm 0.5^{\circ} \mathrm{C}\right)$ inside a culture room. For toxicity studies analytical grade of $\mathrm{Pb}\left(\mathrm{NO}_{3}\right)_{2}$ was used as test solutions at various concentrations. For each concentration of $\mathrm{Pb}\left(\mathrm{NO}_{3}\right)_{2}$ and control three replicates were taken. All the parameters were measured at three days interval till $15^{\text {th }}$ day of exposure. 


\section{Measurement of Growth:-}

Measurement of growth was performed using light scattering technique by monitoring absorbance at $760 \mathrm{~nm}$ in a UV-Visible spectrophotometer (Shimadzu model UV-150-02) at 3 days intervals.

\section{Estimation of Protein:-}

Protein quantification was done following the method of Lowry et al., (1951) and absorbance was recorded at 750 $\mathrm{nm}$ against appropriate blank. Standard curve was prepared by taking different concentrations of bovine serum albumin (BSA). The protein content was calculated as $\mu \mathrm{g}$ of protein/ $\mathrm{ml}$ of algal suspension.

\section{Estimation of Chlorophyll:-}

Chlorophyll content was determined following the methodology of Mackinney(1941). The absorbance of the clear extract was measured at $660 \mathrm{~nm}$ in a UV-visible spectrophotometer (Shimadzu, model UV-150-02).

\section{Estimation of Carotenoid:-}

Carotenoids were estimated as per the method of Jensen(1978). Algal samples were harvested by homogenization and pellets were suspended in $3 \mathrm{ml}$ of $80 \%$ chilled acetone. Then subjected to repeated thawing and freezing followed by centrifugation and supernatant collected. The process was repeated till the supernatant became colorless. The absorbance of the final volume was recordedat $470 \mathrm{~nm}$.

\section{Measurement of MDA Accumulation:-}

The amount of maliondialdehyde, a product of thylakoid lipid peroxidation was estimated according to Du and Bramlage (1992). Thiobarbituric acid (0.5\% in 20\% TCA) was added to equal volume of algal suspension and kept in a water bath at $95^{\circ} \mathrm{C}$ for 25 minutes and then centrifuged at $3000 \mathrm{rpm}$ for 5 minutes for clarification. Absorbance of the clear solution was measured at $532 \mathrm{~nm}$ and corrected for non-specific turbidity by substracting absorbance at $600 \mathrm{~nm}$. The amount of accumulated MDA was estimated by using an absorption coefficient of $155 \mathrm{mM} / \mathrm{ml}$.

\section{Measurement of Photosynthetic Efficiency:-}

Photosynthetic efficiency of algal suspension in terms of chlorophyll fluorescence was measured in a Plant Efficiency Analyzer (Handy PEA, Hansatech Instruments, Norfolk,UK). The algal suspension was dark-adapted for 20 minutes before the measurements and then Fo, Fm and Fv/Fm were analysed by the Handy PEA. The calculation of the rate for competing energy dissipation pathways in the sample of dark adapted (Fo) and light saturated (Fm) conditions had shown that maximal fluorescence $(\mathrm{Fv} / \mathrm{Fm})$ is directly proportional to the quantum efficiency of PS-II.

\section{Assay of Superoxide Dismutase (SOD) Activity:-}

The SOD activity was measured by the method of Dhindsaet al., 1981. The cyanobacterial cells were harvested by centrifugation and homogenized in $2 \mathrm{ml}$ of $0.5 \mathrm{M}$ Phosphate buffer $(\mathrm{pH} 7.5)$. The homogenate was centrifuged at $15,000 \mathrm{rpm}$ at $4^{\circ} \mathrm{C}$ for $10 \mathrm{~min}$ and the supernatant obtained was used as enzyme extract. All the steps in the preparation of enzyme extract were carried out at $0-4^{\circ} \mathrm{C}$. SOD activity in the supernatant was assayed by its ability to inhibit photochemical reduction of nitro blue tetrazolium (NBT). The test tube containing assay mixture $1.5 \mathrm{ml}$ reaction buffer (0.1M Phosphate buffer pH-7.8 + 0.5M Phosphate buffer pH-7.5), $0.2 \mathrm{ml}$ of $200 \mathrm{mM}$ methionine, 0.1 $\mathrm{ml}$ of $1 \mathrm{M} \mathrm{Na}_{2} \mathrm{CO}_{3}, 0.1 \mathrm{ml}$ of $2.25 \mathrm{mM} \mathrm{NBT}, 0.1 \mathrm{ml}$ of $3 \mathrm{mM}$ EDTA, $0.1 \mathrm{ml}$ of $60 \mu \mathrm{M}$ Riboflavin and $0.1 \mathrm{ml}$ enzyme extract. Riboflavin was addedat the last and the tubes were shaken and placed for 50 min below a light bank consisting of $15 \mathrm{~W}$ fluorescent lamps. The tubes were kept in light for 10 minutes and then kept in darkness covered with a black cloth. The absorbance of the reaction mixture was read at $560 \mathrm{~nm}$. A non-irradiated reaction mixture which did not develop colour, served as control.

\section{Heterocyst Frequecy:-}

Heterocyst frequency was determined by counting the number of heterocyst per hundred vegetative cells in at least 20-25 healthy and equal length filaments at different locus as well as within the filament taken atdifferent concentration by the formula given below.

Heterocyst frequency $=$ Total number of heterocyst $/$ Total number of vegetative cells $\times 100$

\section{Results:-}

The heavy metal toxicity is better observed by changes in growth conditions. Gradually decrease in growth was observed with increase in the lead $\left(\mathrm{Pb}^{+2}\right)$ concentration and days of inoculation as compared to control (Fig.1). The 
total protein content of Anabaena $s p$ under $\mathrm{Pb}^{+2}$ treated and control condition also showed the similar trend (Fig.2). As the $\mathrm{Pb}^{+2}$ concentration increases, the total protein accumulation rate decreases.

Chlorophyll $a$ (Fig.3) and carotenoid accumulation (Fig.4.) and loss follow the same trend as observed in growth curve. The negative effect of $\mathrm{Pb}^{+2}$ on Chla and Car content was noticed clearly and the effect increased by the increasing concentration.

Measurement of MDA accumulation (Fig.5) showed a linear increase in control as well as in all concentrations of $\mathrm{Pb}^{+2}$ treated samples. The level gradually increased as the time and concentration of heavy metal increased. However, control sample showed minimum peroxidation value throughout the experimental period of 15 days.

The data on the measurement of Fv/Fm during the laboratory incubation of the samples (Fig.6) show similar kinetics like that of the photosynthetic pigment and protein accumulation and loss of Anabaena $s p$ in control and treated samples. As the concentration of lead increased, photosynthetic efficiency decreased. Lead particularly at higher concentration may directly or indirectly cause damage to D1 protein of PS II leading to photo inhibition (Bhattacharyya et al., 2011). Kinetics of SOD activity (Fig.7) follows kinetic almost same pattern of MDA accumulation. A significant increase in SOD activity were observed as the concentration of lead increased. The heterocyst frequency (Fig. 8) decreases with increase in lead concentration, higher concentration were found inhibitory showing complete death of the cyanobacterium with no sign of heterocyst.

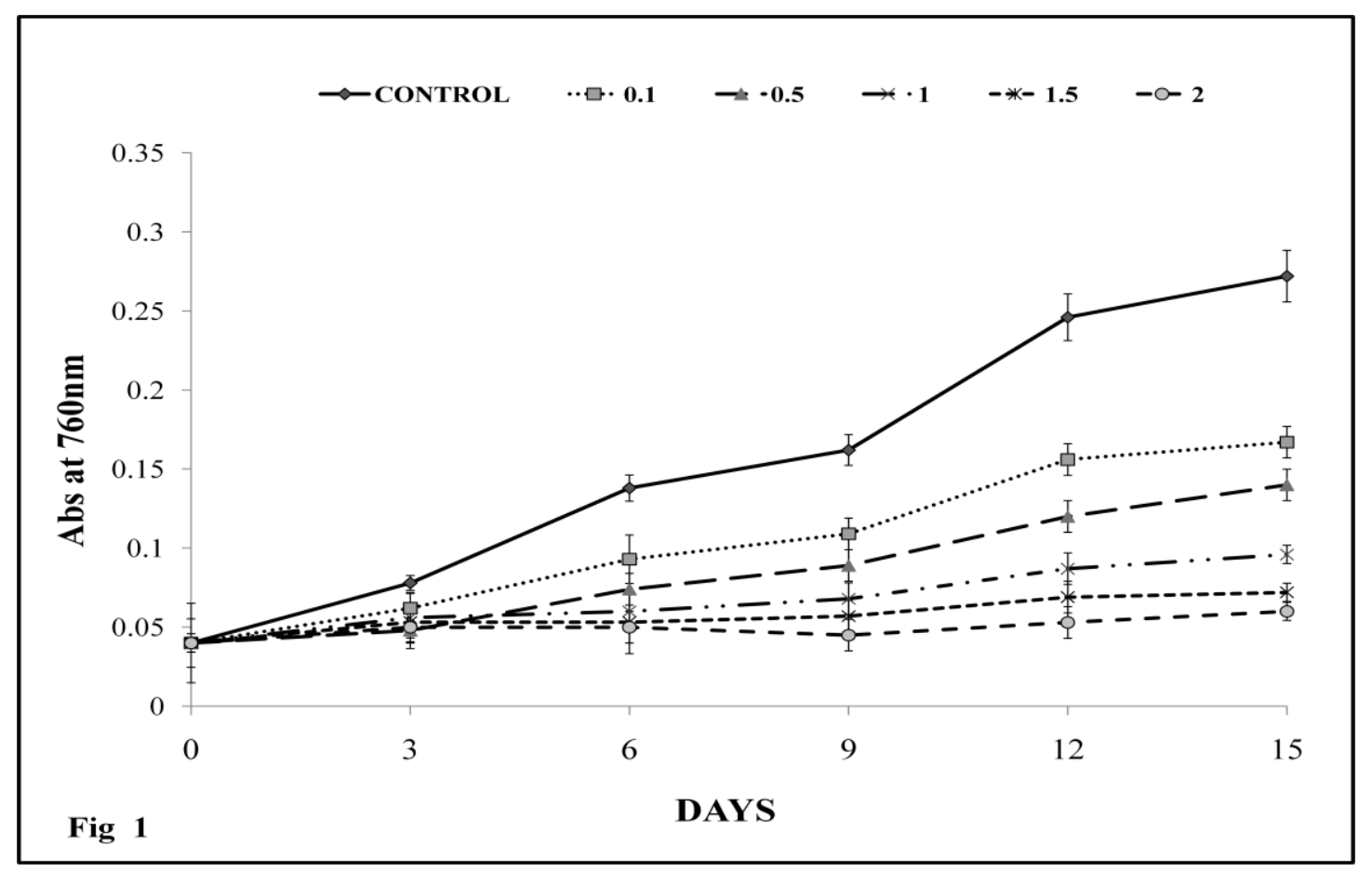

Fig 1:-Effect of lead on Growth of Anabaena sp. 


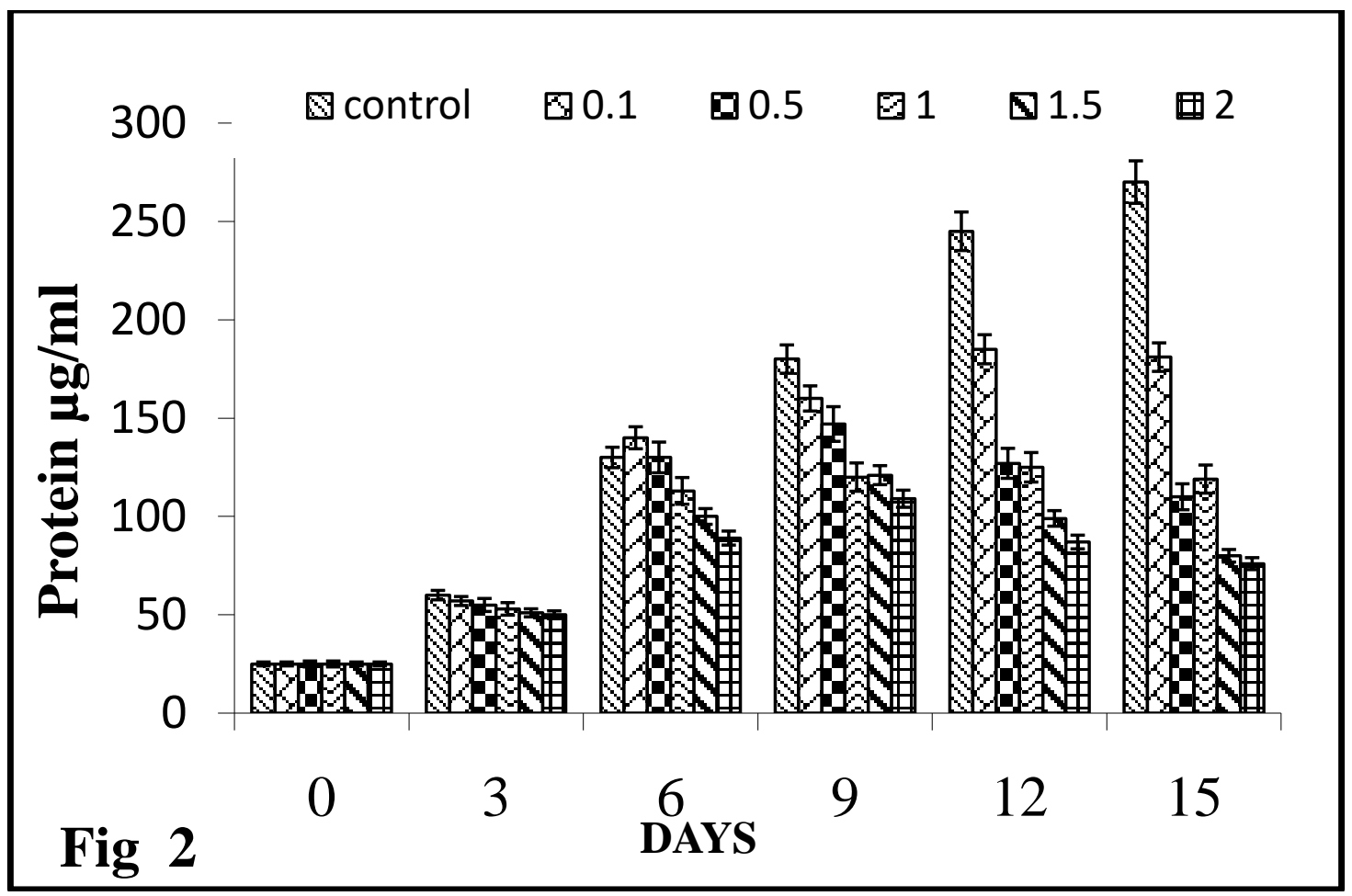

Fig 2:- Effect of lead on total protein content of Anabaena sp.

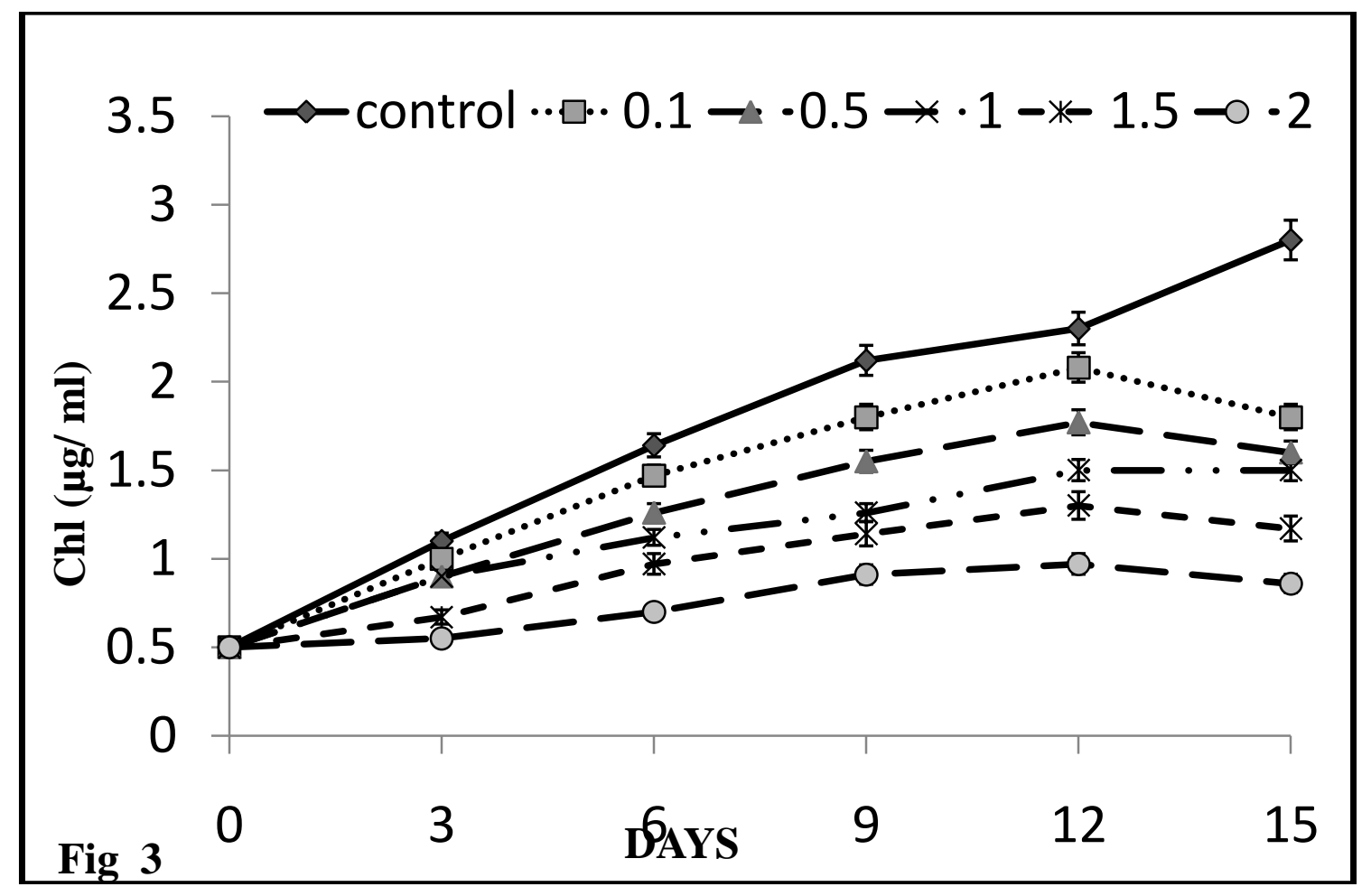

Fig 3:-.Effect of lead on Chlacontent of Anabaena sp 


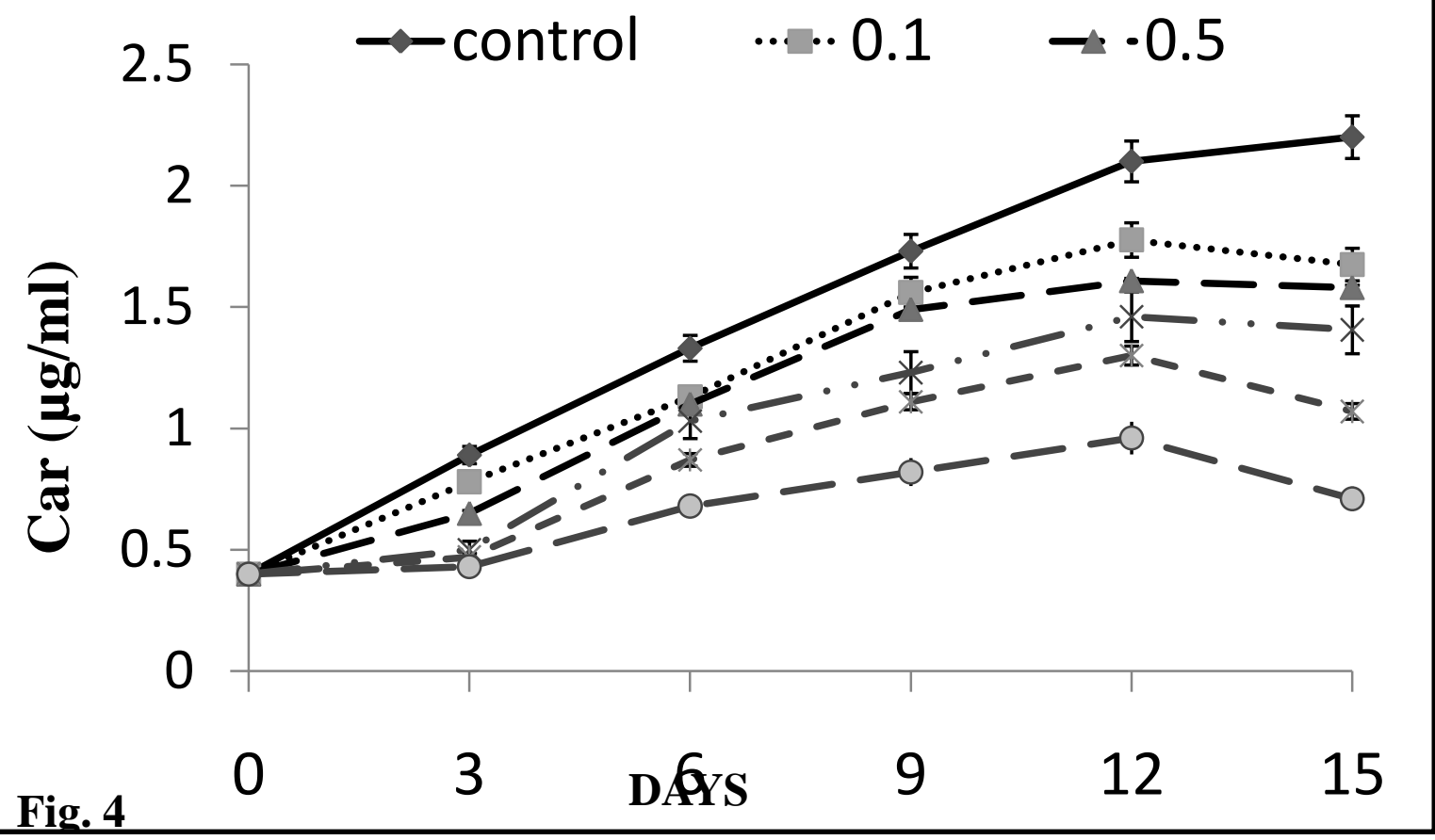

Fig 4:- Effect of lead on carotenoidcontent of Anabaena sp.

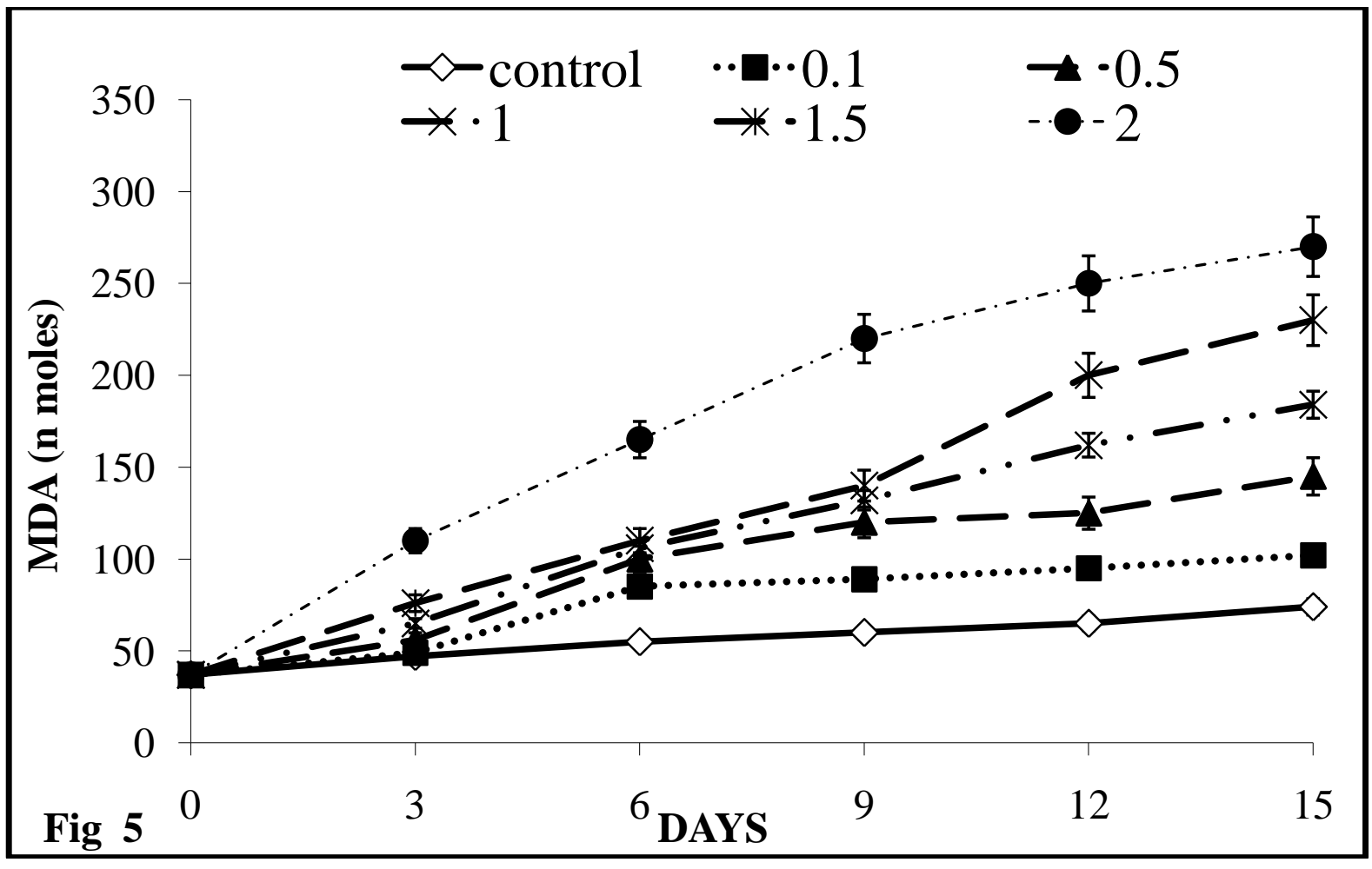

Fig 5:- Effect of lead on MDA accumulation of Anabaena sp 


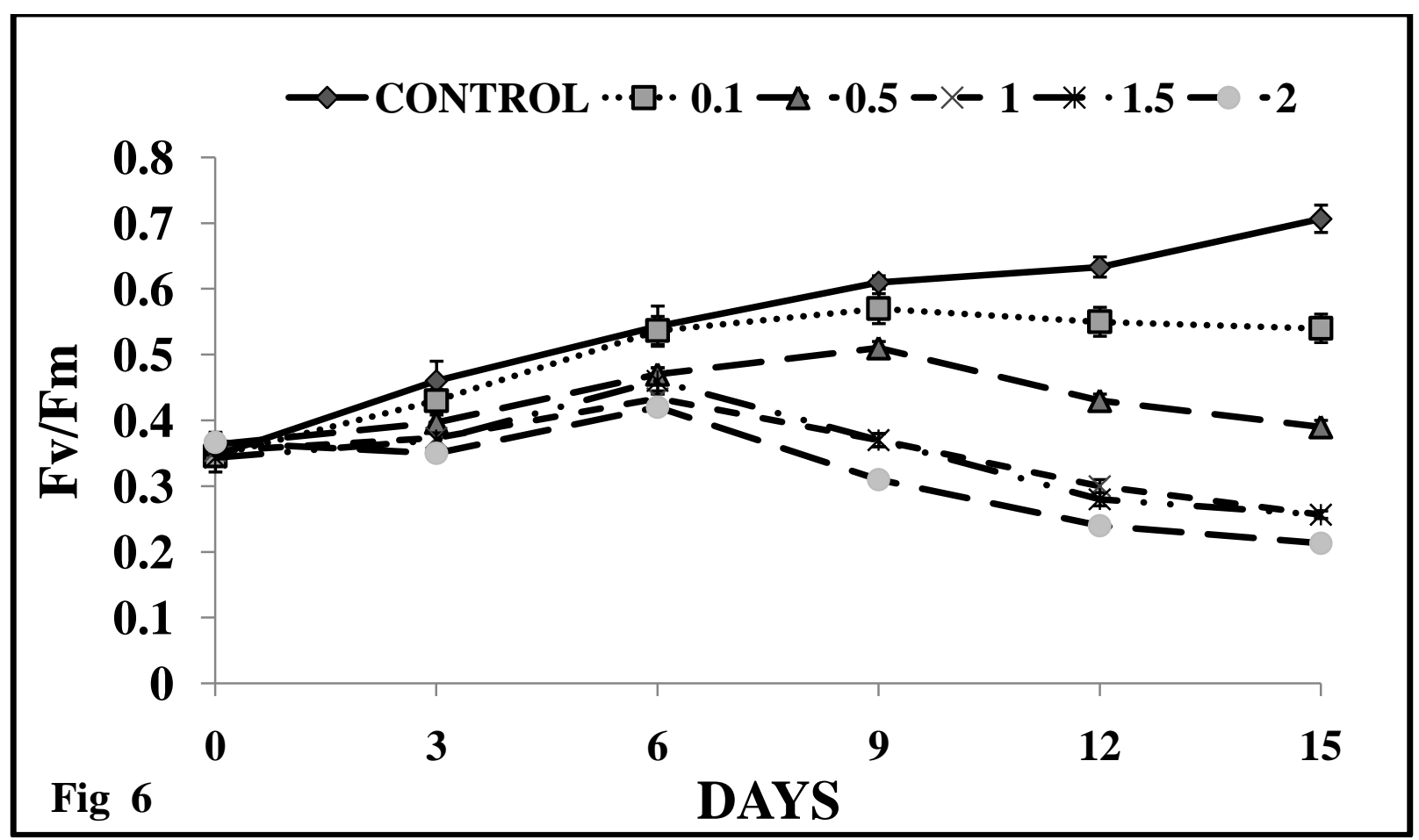

Fig 6:- Effect of lead on photosynthetic efficiency of Anabaena sp

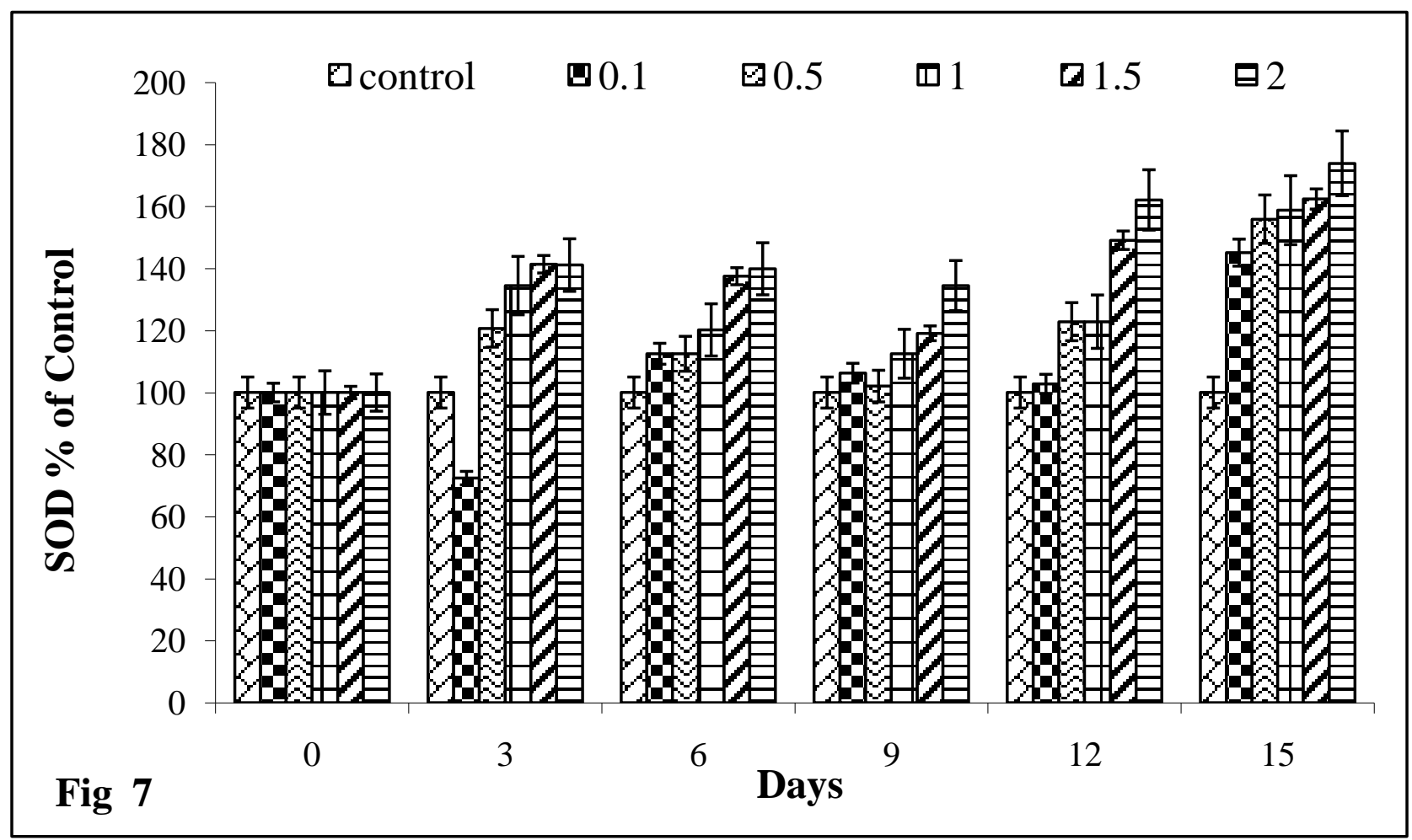

Fig 7:- Effect of lead on SOD activity of Anabaena sp 


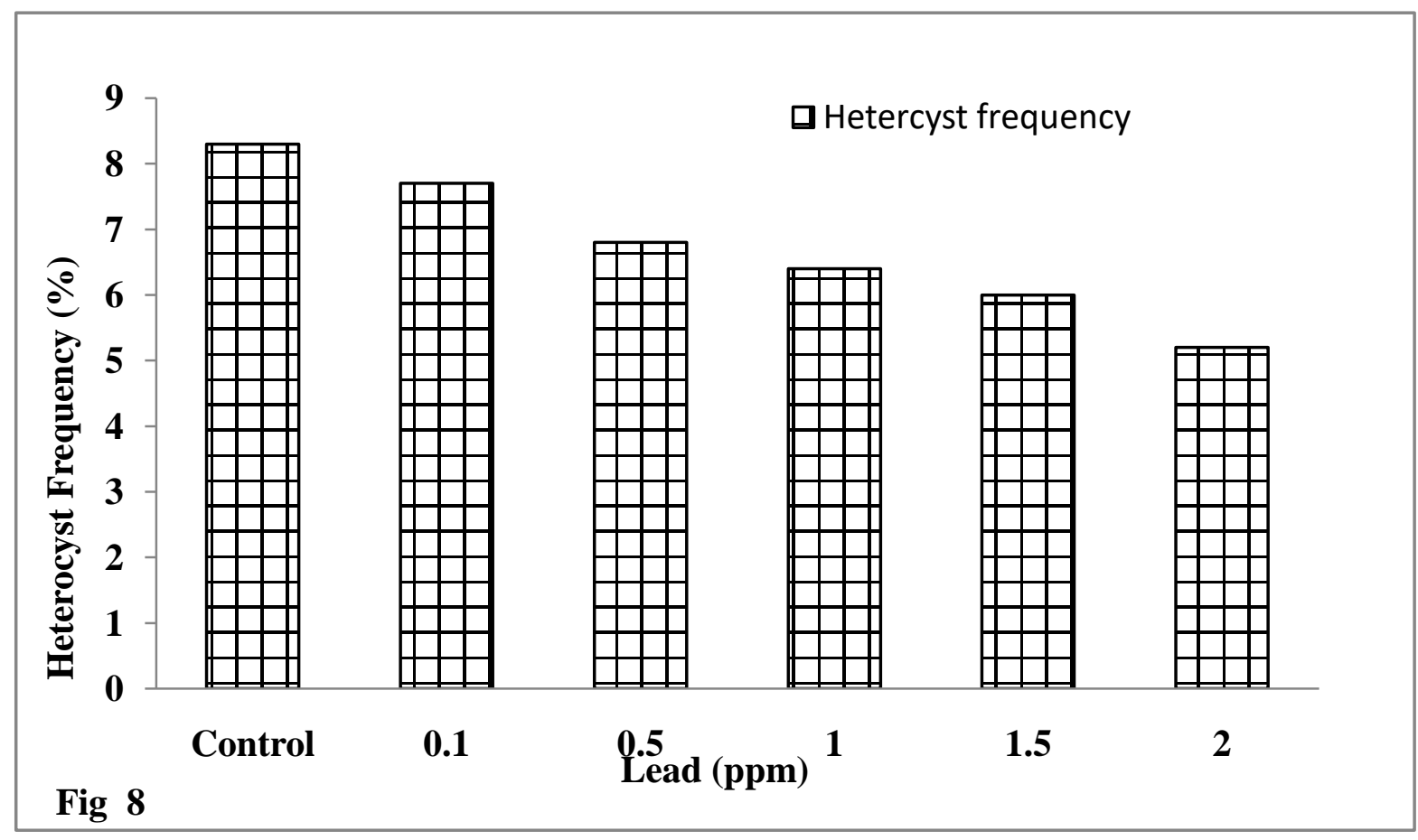

Fig 8:- Effect of lead on heterocyst frequency of Anabaena $s p$

\section{Discussion:-}

Unlike higher plants, cyanobacteria can adopt to nutritional stress and other environmental changes quite readily (Reuter \& Muller, 1993). Toxicity effect of different concentrations of lead and cadmium like damaged and reduced numbers of chloroplasts, disintegrated cell wall and death, decrease in growth and total chlorophyll content with increase in exposure time and concentration in filamentous green algae Cladophorafracta has been reported by Lamia et al., 2005. Another study was reported by El-Sheeket al., 2005 on toxicity effect of copper, manganese, iron and zinc on Anabaena subcylindricaandNostocmuscorum.

In this study the reduction in growth (fig.1)could be due to inhibition of normal cell division by the metal, as reported inDunaliellatertiolecta exposed to mercury and Chlorella vulgaris exposed to copper, mercury and cadmium (Rosko and Rachlin, 1977). However, there is increase in pigment content at low concentration of $\mathrm{Pb}^{+2}$ also agrees with the findings of Rath (1984), Sahu (1987) and Shaw (1987).They reported increased growth rate, increase in pigment content, photosynthetic rate, respiration rate and enzyme activity at low concentration of mercurial compounds on Westellopsisprolifica. Ranaetal., 2010 also reported that growth rate decreased in Lyngbyasp with increase in lead concentration.

Loss in protein content was observed (fig.2) as the time of incubation and concentration of lead increased. Thisfinding supports the results reported by Ybarra and Webb, 1999; El-Enany and Issa, 2000, on the protein content of cyanobacteria. Low level of protein in treated samples could be due to stimulation of non-specific proteases causing degradation of macromolecules (Anand and Subramanium, 1997). This decrease in protein content may also be correlated with the accumulation and loss of phycobiliprotein which constitute up to $50 \%$ of total soluble cellular protein (Grossman et al., 1993, MacColl, 1998). Heavy metal concentration showed gradual decrease in protein content with increase of metal concentration in Anabaenaflos-aquae (Surosz and Palinska, 2004).

De Filippiset al., 1981 reported that the reduction in chlorophyll $a$ content is a common symptom of heavy metal toxicity. Carotenoid plays an important role in photoprotection of chlorophyll (Deo and Biswal, 2001) by quenching the triplet Chlorophyll and scavenging the singlet oxygen and other reactive oxygen species (ROS) (Choudhury and Behera, 2001). Edwin, 1997; Moreland, 1980; Bhuniaet al., 1991 suggested that the loss of carotenoid accumulation may be due to the inhibition of carotenoid biosynthesis pathway leading to chlorosis of the organism or may be due 
to degradation membrane component of the thylakoid (Allen, 1984). In the present work, the low level of chlorophyll (fig.3) and carotenoid content (fig.4)in lead treated samples supports the observations of Das and Adhikary (1996), Sikha and Singh (2004) and Xia (2005).

One of the deleterious effects induced by heavy metal exposure in plants, algae and cyanobacteria is lipid peroxidation, which can directly causes biomembrane deterioration. Malionaldehyde (MDA) is regarded as a reliable indicator of oxidative stress (Demiral and Turkan, 2005). Lipid peroxidation expressed as MDA accumulation was reported to be high under heavy metal stress (Gallegoetal., 1996; Cho and Park 2000; Shah etal., 2001). In cyanobacteria, the lipids present in the thylakoid membranes contain a high percentage of polyunsaturated fatty acid (PUFA) residues and are thus most susceptible to peroxidation (Halliwell 1999; Bandopadhyayet al., 1999). Production of ROS during stress condition in cyanobacteria have been reported (Hideg and Vaas, 1996) which followed a series of damaging reactions with biological molecules resulting in enhanced production of MDA in treated samples. Free radical formation occurs due to strong inhibition of PS II. These active oxygen species $\left(\mathrm{O}^{-}\right.$ ${ }_{2}, \mathrm{H}_{2} \mathrm{O}_{2}, \mathrm{OH},{ }^{1} \mathrm{O}_{2}$ ) causes severe toxicological problems and results in peroxidation of membrane lipids and general cellular oxidation. The present result is also in agreement with the above results and also with the reports of(Choudhuryet al., 2007; Fatmaet al., 2007) on Spirulinaplatensis and Westellopisprolifica.

Photosynthetic efficiency of PS II can be measured by the ratio of Fv/Fm. It is known that photo inhibition occurs when the rate of excitation energy captured exceeds the rate of consumption in photosynthetic reactions (Osmond, 1981; Powles, 1984). Photo inhibition in terms of $\mathrm{F}_{\mathrm{v}} / \mathrm{F}_{\mathrm{m}}$ has been found both in higher plants (Panda et al., 2006; Rodrigues et al., 2007) as well as in algae (Ying and Hader, 2002; Xia, 2005). The primary site of photo inhibition is the reaction centre (D1 protein) of PS II (Demming and Bjorkman, 1987). Photo inhibition is manifested as a decrease in oxygen evolution (Krause, 1988) and photochemical efficiency (Falk and Samuelsson, 1992). Photosynthetic functions also have been found to be affected directly or indirectly by heavy metals since thylakoids lamelle of cyanobacterialcells contain all chlorophylls and carotenoids, which are disassembled in the presence of heavy metals (Baszynski and Krupa, 1995; Prasad etal., 2002). Decrease in Fv/Fm ratio in the present investigation (fig.6) supports the earlier findings.

$\mathrm{Pb}^{+2}$ ions can intensify processes of ROS production leading to oxidative stress (Cuyperset al., 1999). Among the four major active oxygen species super oxide radicals $\mathrm{O}_{2}, \mathrm{H}_{2} \mathrm{O}_{2}$, hydroxyl radicals are most active and destructive. SOD and catalase (Asada 1994)activity enhances under a variety of stressful condition like $\mathrm{Cu}, \mathrm{Al}, \mathrm{Mn}, \mathrm{Fe}, \mathrm{Zn}, \mathrm{Pb}$ toxicities (Prasad, 1994) for maintenance of overall defense system of cell subjected to oxidative damage (Slootenet al., 1995). In our findings, increased SOD activity (fig.7) was observed with increase in metal concentration and day of incubation.

Heterocyst frequency count is a measure of the rate of nitrogen fixation by BGA (William et al., 1970). Among the filamentous BGA, the ability to fix nitrogen under aerobic conditions is strictly correlated with the ability to form heterocyst (Stewart, 1969). In the present investigation, the heterocyst frequency (fig.8) decreased at higher metal concentration. This could be either due to the inhibited synthesis of proteins involved in heterocyst differentiation or due to degradation of pre-existing heterocyst. The increased in heterocyst frequency may be due to impaired nitrogen fixation due to lack of functional nitrogenase enzyme (Orus and Marco, 1991).

\section{References:-}

1. Allen, M.M. 1984: Cyanobacterial cell inclusions. Annu. Rev. Microbiol., 38: 1-25.

2. Anand, N. and Subramanian, T.D. 1997: Effect of certain heavy metals on the physiology of Nostoccalcicola. Phykos, 36: 15-20.

3. Asada, K. 1994: Production and action of active oxygen species in photosynthetic tissues. In Causes of photooxidative stress and amelioration of defence systems in plants (ed. Ch. F. Foyer \& P. M. Mullineaux), pp.77-104. Boca Raton, FL: CRC Press.

4. Atkinson B. W., Bux F., Kasan H. C., 1998, Waste activated sludge remediation of metal plating effluents, Water S. A., 24(4), 355-359

5. Bandopadhyay, U. Das, D. and Banerjee, R.K. 1999. Reactive oxygen species: Oxidative damage and pathogenesis. Current Science. 77: 658-666.

6. Baszynski, T. and Krupa, Z., 1995. Some aspects of heavy metals toxicity towards photosynthetic apparatusdirect and indirect effects on light and dark reactions. ActaPhysiologiaePlantarum, 17(2), pp.177-190. 
7. Bayramoğlu, G. and Arıca, M.Y., 2008. Removal of heavy mercury (II), cadmium (II) and zinc (II) metal ions by live and heat inactivated Lentinusedodes pellets. Chemical Engineering Journal, 143(1), pp.133-140.

8. Bhunia, A.K. Basu, N.K. Roy, D. Chakrabarti, A. and Banerjee, S.K. 1991: Growth and chlorophyll a content, nitrogen fixing ability and certain metabolic activities of Nostocmuscorum : Effect of methylparathion and benthiocarb. Bull. Environ. Contam. Toxicol., 47: 43-50.

9. Cho, U.H. and Park, J.O., 2000. Mercury-induced oxidative stress in tomato seedlings. Plant Science, 156(1), pp.1-9.

10. Choudhary M., Jetely UK, Khan A., Zutshi S. and Fatma T. 2007: Effect of heavy metal stress on proline and malondialdehyde and superoxidismutase activity in cyanobacteriumSpirulinaplatensis S5. Ecotoxicol Environ Saf. 66: 204-209.

11. Choudhury, N.K. and Behera, R.K., 2001: Photoinhibition of photosynthesis: Role of carotenoids in photoprotection of chloroplast. Photosynthetica, 39: 481-488.

12. Cuypers A., Vangronsveld J. and Clijsters H. 1999. The chemical behavior of heavy metals plays a prominent role in the induction of oxidative stress. Free Rad. Res. 31: 539-543.

13. Das, M.K. and Adhikary, S.P. 1996: Toxicity of three pesticides on several rice field cyanobacteria. Trop. Agric. (Trinidad), 73(2): 155-157

14. De Filippis, L.F., Hampp, R. and Ziegler, H., 1981. The effects of sublethal concentrations of zinc, cadmium and mercury on Euglena. Archives of Microbiology, 128(4), pp.407-411.

15. Demiral, T. and Türkan, I., 2005. Comparative lipid peroxidation, antioxidant defense systems and proline content in roots of two rice cultivars differing in salt tolerance. Environmental and Experimental Botany, 53(3), pp.247-257.

16. Demmings-Adams B. and Bjorkman O. 1987: Comparison of the effect of excessive light on schlorophyll fluorescence (77k) and photon yield of $\mathrm{O}_{2}$ evolution in higher plants. Planta. 171: 171-184.

17. Deo, P.M. and Biswal, B. 2001: Response of senescing cotyledons of clusterbean to water stress in moderate and low light: Possible photoprotective role of $\beta$-carotene. Physiol. Plant., 112: 47-5.

18. Dhindsa S Rajinder, Dhindsa.P.Plumb.,Thorpe.Trevor.A, 1981. Leaf senescence correlated with increased levels of membrane permeability and lipid peroxidation, and decreased levels of SOD and catalase, .J.Exp.Bot,Vol.32,No.126,pp.93-101.

19. Doshi, H., A. Ray and I. L. Kothari, (2007b). Bioremediation potential of live and dead Spirulina: spectroscopic, kinetics and SEM studies. Biotechnol. Bioeng. 96(6): 1051-1063.

20. Du Z. and Bramlage, W.J. 1992: Modified thiobarbituric acid assay for measuring lipid peroxidation in sugar rich plant tissue extracts. J. Agric. Food Chem., 40: 1566-1570.

21. Edwin S. 1997: Action of Methyl Parathion on Algal Metabolism. M.Phil Thesis, Madurai University, Madurai, India.

22. El-Enany, A.E. and Issa, A.A., 2000. Cyanobacteria as a biosorbent of heavy metals in sewage water. Environmental Toxic Pharm,8(2), pp.95-101.

23. El-Sheekh, M., El-Shouny, W., Osman, M. and El-Gammal, E. 2005.Growth and heavy metals removal efficiency of Nostocmuscorumand Anabaena subcylinderica in sewage and industrial wastewater effluents. Envi. Toxicol. Pharma. 19: 357-365.

24. Falk, S. and Samuelsson, G. 1992: Recovery of photosynthesis and photosystem II fluorescence in Chlamydomonasreinhardtii after exposure to three levels of high light. Physiol. Plant., 85: 61-68.

25. Fatma, T., Khan, M.A. and Choudhary, M., 2007. Impact of environmental pollution on cyanobacterialproline content. Journal of Applied Phycology,19(6), pp.625-629.

26. Fay, P., 1992. Oxygen relations of nitrogen fixation in cyanobacteria. Microbiological Reviews, 56(2), pp.340373.

27. Feris K, Ramsey P, Frazar C, Moore JN, Gannon JE, Holben WE. Differences in hyporheic-zone microbial community structure along a heavy-metal contamination gradient. Appl Environ Microbiol 2003;69:5563-73.

28. Foyer, C.H., M. Lelendais and K.J. Kunert 1997. Photoxidative stress in plants. Physiol. Plant. 92:696-717

29. Gallego, S.M., Benavides, M.P. and Tomaro, M.L., 1996. Effect of heavy metal ion excess on sunflower leaves: evidence for involvement of oxidative stress. Plant Science, 121(2), pp.151-159.

30. Gavrilescu, M., 2004. Removal of heavy metals from the environment by biosorption. Engineering in Life Sciences, 4(3), pp.219-232.

31. Goyal, N., S.C. Jain, and U.C. Banerjee. 2003. Comparative studies on the microbial adsorption of heavy metals. Adv. Environ. Res. 7:311-319.

32. Grossman, A.R; Schaefer, M.R; Chiang, G.G. and Collier, J.C. 1993: The phycobilisome, a light harvesting complex responsive to environmental conditions. Microbiol. Rev., 57: 725-749. 
33. Halliwell B. and Gutteridge J.M.C. 1999. Free Radicals in Biology and Medicine, $3^{\text {rd }}$ Edition, Oxford, New York.

34. Hemlata and T. Fatma. 2009. Screening of cyanobacteria for phycobiliproteins and effect of different environmental stress on its yield. Bull. Environ. Contam. Toxicol. 83: 509-515

35. Henick-Kling, T. and Stoewasnd, G. 1993. Lead in wine. Amer. J.Enolo. Viticul. 44: 459-463.

36. Hideg, E. \& Vass, I. 1996. UV-B induced free radical production in plant leaves and isolated thylakoid membranes. Plant Sci.

37. Incharoensakdi, A. and P. Kitjaharn (1998). Removal of lead from aqueous solution by filamentous cyanobacterium, Spirulinaplatensis. J. Sci. Res. Chula Univ. 23: 38-44

38. Isani, G., Andreani, G., Cocchioni, F., Fedeli, D., Carpene, E. and Falcioni, G., 2009. Cadmium accumulation and biochemical responses in Sparusaurata following sub-lethal Cd exposure. Ecotoxicology and environmental safety, 72(1), pp.224-230.

39. Jensen, A. 1978: Chlorophyll and carotenoids: In: J.A. Hellebust and J.S. Craiyie (Eds.), Handbook of Physiological, Phycological and Biochemical Methods, Cambridge University Press, London, pp.59-70

40. Khattar, J.I., Sarma, T.A. and Sharma, A., 2007. Optimization of chromium removal by the chromium resistant mutant of the cyanobacteriumAnacystisnidulans in a continuous flow bioreactor. Journal of Chemical Technology and Biotechnology, 82(7), pp.652-657.

41. Kitjaharn, P. and A. Incharoensakdi (1992). Factors affecting the accumulation of lead by Aphanothecehalophytica. J. Sci. Chula. 17: 141-147.

42. Krause, G.H. 1988: Photoinhibition of photosynthesis - An evaluation of damaging and protective mechanisms. Physiol. Plant, 74: 566-574.

43. Krupa Z, Öquist G, Huner N (1993) The effects of cadmium on photosynthesis of Phaseolus vulgaris-a fluorescence analysis. Physiol Plant. 88: 626-630

44. Kumar, J.N., Oommen, C. and Kumar, R.N., 2009. Biosorption of heavy metals from aqueous solution by green marine macroalgae from Okha Port, Gulf of Kutch, India. American-Eurasian J. Agric. \& Environ. Sci, 6(3), pp.317-323.

45. Lamai, C., Kruatrachue, M., Pokethitiyyook, P., Upatham, E. and Soonthornsarathool, V. 2005. Toxicity and accumulation of lead and cadmium in the filamentous green alga Cladophorafracta (O.F.Muller ex Vahl) Kutzing: a laboratory study. Sci. Asia. 31: 121-127

46. Lowry, O. H., N. J. Rosenbrought, A. L. Farr and R. J. Randall 1951.Protein measurements with Folin -Phenol reagent. J. Biochem., 193, 265-275

47. MacColl, R. 1998: Cyanobacterialphycobilisomes. J. Struct. Biol., 124: 311-334.

48. Mackinney, G., 1941. Absorption of light by chlorophyll solutions. J. biol. Chem, 140(2), pp.315-322.

49. Malik, A., 2004. Metal bioremediation through growing cells. Environment international, 30(2), pp.261-278.

50. Malkoc, E. and Nuhoglu, Y., 2005. Investigations of nickel (II) removal from aqueous solutions using tea factory waste. Journal of Hazardous Materials, 127(1), pp.120-128.

51. Marschner H 1995 Mineral Nutrition of Higher Plants. pp 379-396. Academic Press, San Diego, USA.

52. Matagi, S.V., Swai, D. and Mugabe, R., 1998. A review of heavy metal removal mechanisms in wetlands.

53. Matheickal, J.T. and Yu, Q., 1999. Biosorption of lead (II) and copper (II) from aqueous solutions by pretreated biomass of Australian marine algae.Bioresource technology, 69(3), pp.223-229.

54. Matheickal, J.T., 1998. Biosorption of heavy metals from waste water using macro-algae Durvillaeapotatorum and Eckloniaradiata. Griffith University.

55. Moreland D. E. 1980. Mechanism of action of herbicides. Ann. Rev. Plant Physiol., 31: 597-638.

56. Nakanishi, Y., M. Sumita, K. T. Yamada and T. Honjo 2004. Heavy - metal pollution and its state in algae in Kakehashi river and Godani river at the foot of ogoya mine, Ishikawa Prefecture Anal.Sci.20, 73 - 78

57. Orus, M.I and E, Marco. 1991. Heterocyst structure alteration and $\mathrm{O}_{2}$ mediated inhibition of dinitrogen fixation by trichlorfon in Anabaena.J. Exp. Bot. 42, 1595 - 1600

58. Osmond, C.B. 1981: Photorespiration and Photoinhibition. Biochim. Biophys. Acta, 639: 77-98.

59. Panda, D., Rao, D.N., Sharma, S.G., Strasser, R.J. and Sarkar, R.K., 2006. Submergence effects on rice genotypes during seedling stage: probing of submergence driven changes of photosystemII by chlorophyll a fluorescence induction OJIP transients. Photosynthetica, 44 (1), pp.69-75.

60. Pavasant, P., Apiratikul, R., Sungkhum, V., Suthiparinyanont, P., Wattanachira, S. and Marhaba, T.F., 2006. Biosorption of $\mathrm{Cu} 2+, \quad \mathrm{Cd} 2+, \quad \mathrm{Pb} 2+$, and $\mathrm{Zn} \mathrm{2+}$ using dried marine green macroalgaCaulerpalentillifera.Bioresource Technology, 97(18), pp.2321-2329.

61. Powles, S.B. 1984: Photoinhibition of photosynthesis induced by visible light. Annu. Rev. Plant Physiol., 35: 15-19 
62. Prasad, T.K., Anderson, M.D., Martin, B.A. and Stewart, C.R., 1994. Evidence for chilling-induced oxidative stress in maize seedlings and a regulatory role for hydrogen peroxide. The Plant Cell, 6(1), pp.65-74.

63. Rai, L.C. and Raizada, M., 1985. Effect of nickel and silver ions on survival, growth, carbon fixation and nitrogenase activity in Nostocmuscorum: Regulation of toxicity by EDTA and calcium. The Journal of General and Applied Microbiology, 31(4), pp.329-337.

64. Rai,U.N. R.D. Tripathi,N. Singh,A. Kumar M.B. Alli A Pal and S.N.Singh 2000. Amelioration of Fly-ash by selected Nitrogen fixing blue green algae. Bull. Environ. Cont. Toxicol, 64 294-301

65. Rana, L., Chhikara, S. and Dhankhar, R.2010, Lead Toxicity in Lyngbya sp. Isolated from Sewage Water Irrigated Soil.Environ.we Int. J. Sci. Tech.5:79-85

66. Rath P. 1984: Toxicological effects of pesticides on a blue green algae, Westiellopsisprofilica. Janet. Ph.D thesis, Berhampur University, India.

67. Reuter, W. and Muller, C. 1993: Adaptation of the photosynthetic apparatus of cyanobacteria to light and $\mathrm{CO}_{2}$. J. Phtochem. Photobiol., 21: 3-27.

68. Rodríguez-Calcerrada, J., Pardos, J.A., Gil, L. and Aranda, I., 2007. Summer field performance of Quercuspetraea (Matt.) Liebl and QuercuspyrenaicaWilld seedlings, planted in three sites with contrasting canopy cover. New Forests, 33(1), pp.67-80.

69. Rosko, J.J. and Rachlin, J.W., 1977. The effect of cadium, copper, mercury, zinc and lead on cell division, growth, and chlorophyll a content of the chlorophyte Chlorella vulgaris. Bulletin of the Torrey Botanical Club, pp.226-233.

70. Ryan, J.A. and Chaney, R.L., 1994. Heavy metals and toxic organic pollutants in MSW-composts: Research results on phytoavailability, bioavailability, fate, etc (No. PB-94-155348/XAB; EPA--600/A-94/030). Environmental Protection Agency, Cincinnati, OH (United States). Risk Reduction Engineering Lab..

71. Sahu A. 1987: Toxicological effects of a pesticide on a blue green alga. III. Effect of PMA on a blue green alga, Westiellopsisprofilica. Janet and its ecological implications. Ph.D thesis, Berhampur University, India.

72. Shah, K., Kumar, R.G., Verma, S. and Dubey, R.S., 2001. Effect of cadmium on lipid peroxidation, superoxide anion generation and activities of antioxidant enzymes in growing rice seedlings. Plant Science, 161(6), pp.1135-1144.

73. Shaw B.P. 1987: Eco-physiological studies of industrial effluent of a chlor-alkali factory on biosystems. Ph.D thesis, Berhampur University, India.

74. Shikha and Singh D.P. 2004: Influence of glyphosphate on photosynthetic properties of wild type and mutant strains of cyanobacteriumAnabaena doliolum. Current Science, 86: 571-576.

75. Slooten L.K., Capiau W. Van Camp, M. Van Montagu, C. Sybesma and D. Inze 1995. Factors affecting the enhancement of oxidative stress tolerance in transgenic tobacco over-expressing manganese superoxide dismutase in the chloroplasts. Plant Physiol., 107: 373-380

76. Stanier, R. Y., R. Kunisawa, M. Mandel, and G. Cohen-Basire. 1971. Purification and properties of unicellular blue-green algae (order Chroococcales). Bacteriol. Rev. 35:171-205

77. Startton, G.W., Huber, A.L., Corke, C.T., 1979. Effect of mercuric ions on growth, photosynthesis and nitrogenase activity of Anabaena equalis. Appl. Environ. Microbiol. 38: 537-543

78. Stewart,W.D. A.Haystead and H.W.Pearson 1969. Nitrogenase activity in heterocysts of blue green algae. Nature 224:226-228

79. Stroiński, A, and M Kozłowska 1997. Cadmium-induced oxidative stress in potato tuber. ActaSoc. Bot. Pol. 66: in print.

80. Surosz, W. and Palinska, K.A., 2004. Effects of heavy-metal stress on cyanobacterium Anabaena flosaquae. Archives of environmental contamination and toxicology, 48(1), pp.40-48.

81. Tandeau de Marsac,N. and Houmard,J. 1993. Adaptation of cyanobacteria to environmental stimuli: new steps towards molecular mechanisms. FEMS Microbiol. Rev., 104, 119-190.

82. Thajuddin, N. and Subramanian, G., 2005-Cyanobacterial Biodiversity and potential application in Biotechnology. Current Science, 89(1), pp.47-57.

83. Tien CJ, Sigee DC, White KN (2005) Copper adsorption kinetics of cultured algal cells and freshwater phytoplankton with emphasis on cell surface characteristics. J ApplPhycol 17:379-389

84. Tien, C.J., 2002. Biosorption of metal ions by freshwater algae with different surface characteristics. Process Biochemistry, 38(4), pp.605-613.

85. Tripathy BC, Bhatia B and Mohanty P (1981)Inactivation of chloroplast photosynthetic electron- transport activity by $\mathrm{Ni}^{2+}$. Biochim. Biophys. Acta 638:217-224. 
86. Vijayaraghavan, K., Padmesh, T.V.N., Palanivelu, K. and Velan, M., 2006. Biosorption of nickel (II) ions onto Sargassumwightii: application of two-parameter and three-parameter isotherm models. Journal of hazardous materials, 133(1), pp.304-308.

87. Viner, A.B., 1987. Cyanobacteria in New Zealand inland waters: experimental studies. New Zealand Journal of Marine and Freshwater Research, 21(3), pp.503-507.

88. Volesky, B., 1994. Advances in biosorption of metals: selection of biomass types. FEMS Microbiology Reviews, 14(4), pp.291-302.

89. Volesky, B., 2001. Detoxification of metal-bearing effluents: biosorption for the next century. Hydrometallurgy, 59(2), pp.203-216.

90. Wang, T.C., Weissman, J.C., Ramesh, G., Varadarajan, R. and Benemann, J.R., 1998. Heavy metal binding and removal by Phormidium. Bulletin of environmental contamination and toxicology, 60(5), pp.739-744.

91. Whitton, B.A., 1970. Toxicity of zinc, copper and lead to Chlorophyta from flowing waters. ArchivfürMikrobiologie, 72(4), pp.353-360.

92. Whitton, B.A., Harding, J.P.C. and Say, P.J., 1981. Aquatic mosses as monitors of heavy metal contamination in the River Etherow, Great Britain.Environmental Pollution Series B, Chemical and Physical, 2(4), pp.295307.

93. Xia, J. 2005: Response of growth, photosynthesis and photoinhibition of the edible cyanobacterium $N$. sphaeroids colonies to thiobencarb herbicide. Chemosphere, 59: 561-566.

94. Xyländer, M. and Braune, W., 1994. Influence of nickel on the green alga HaematococcuslacustrisRostafinski in phases of its life cycle. Journal of plant physiology, 144(1), pp.86-93.

95. Ybarra, G.R. and Webb, R., 1999. Effects of divalent metal cations and resistance mechanisms of the cyanobacteriumSynechococcus sp. strain PCC 7942. J. Hazard. Subst. Res, 2, pp.1-9.

96. Ying-Yu, $\mathrm{H}$ and Hader,D.P. 2002: UV-B induced formation of ROS and oxidative damage of the cyanobacteriumAnabaena sp. Protective effects of ascorbic acid and N-acetyl-Ccystein.J.Photochem.Photobiol.,66:115-124 